堆 積 学 研 究, 52号, 63-74, 2000

J.Sed.Soc.Japan, No. 52，63-74， 2000

中部更新統下総層群数層から復元された砂嘴一内湾システム

岡崎 浩子*·佐藤 弘幸**・中里 裕臣 ${ }^{* * *} \cdot$ 鎌滝 孝信****

\title{
Spit-bay depositional system recognized in the Yabu Formation, Shimosa Group in the Kisarazu Plateau, Chiba Prefecture, Japan
}

\author{
Hiroko Okazaki*, Hiroyuki Sato**, Hiroomi Nakazato*** \\ and Takanobu Kamataki****
}

The middle Pleistocene Yabu Formation, Shimosa Group distributed in the Shimosa Plateau is deposits of Paleo Tokyo-Bay. The investigation area, Kisarazu Plateau is located at the most southern part of the Shimosa Plateau and also the southern margin of Paleo Tokyo-Bay. The Yabu Formation is mainly composed of sands, and alternation of sands and muds. We exhibit the distribution of Yabu Formation at the Kisarazu Plateau, using intercalated volcanic ashes and examining a depositional system by facies analysis.

As a result, spit-bay depositional system was reconstructed at the heads of Paleo Tokyo-Bay from the shape of basin and facies distribution of the formation. In addition, the change of depositional system in the Yabu Formation was considered. Consequently, the depositional sequence corresponding to a glacio-eustatic sea-level change was recognized in the formation, and it became clear that the spit developed durig taransgression associated with interglacial period and the bay was filled and diminished during subsequent sea-level lowering.

Key words : spit, depositional system, the Yabu Formation, middle Pleistocene, glacioeustatic sea level change

受付 : 2000 年 9 月 28 日 受理 : 2000 年 11 月 28 日

* 千葉県立中央博物館地学研究科

Natural History Museum and Institute, Chiba 955-2 Aoba-cho, Chuo-ku, 260-8682 Japan : E-mail, kohiroko @chiba-muse.or.jp

** 静岡聖光学院中・高等学校

Shizuoka Seikogakuin Junior and Senior High School, Shizuoka 422-8021, Japan

*** 農業工学研究所

National Research Institute of Agricaltural Engineering, Tsukuba 305-8609, Japan

**** 東濃地科学センター

Tono Geoscience Center, Toki, Gifu 509-5102, Japan

\section{はじめに}

中・上部更新統下総層群は, 房総半島中北部に広 がる下総台地を構成する主に浅海成の砂層からな り, 古東京湾と呼ばれる内海の堆積物である。下総 層群は下位加, 地蔵堂層, 薮層, 上泉層, 清川層, 木下層, 姉崎層（竜ヶ崎層）汃らなる，各累層の堆 積時期はほぼ氷河性海水準変動の 10 万年周期に対 応している（杉原ほか，1978; 増田，1988）。調査地 域である木更津台地は, 下総層群分布地域の南限す なわち古東京湾の南縁にあたる。下総層群の下部層 である薮層は下総台地に広く分布し, 挟在するテフ ラのフィッショントラック年代は約 30 万年前を示 す。本論文では，調査地域で新たに報告された指標 


\section{a}

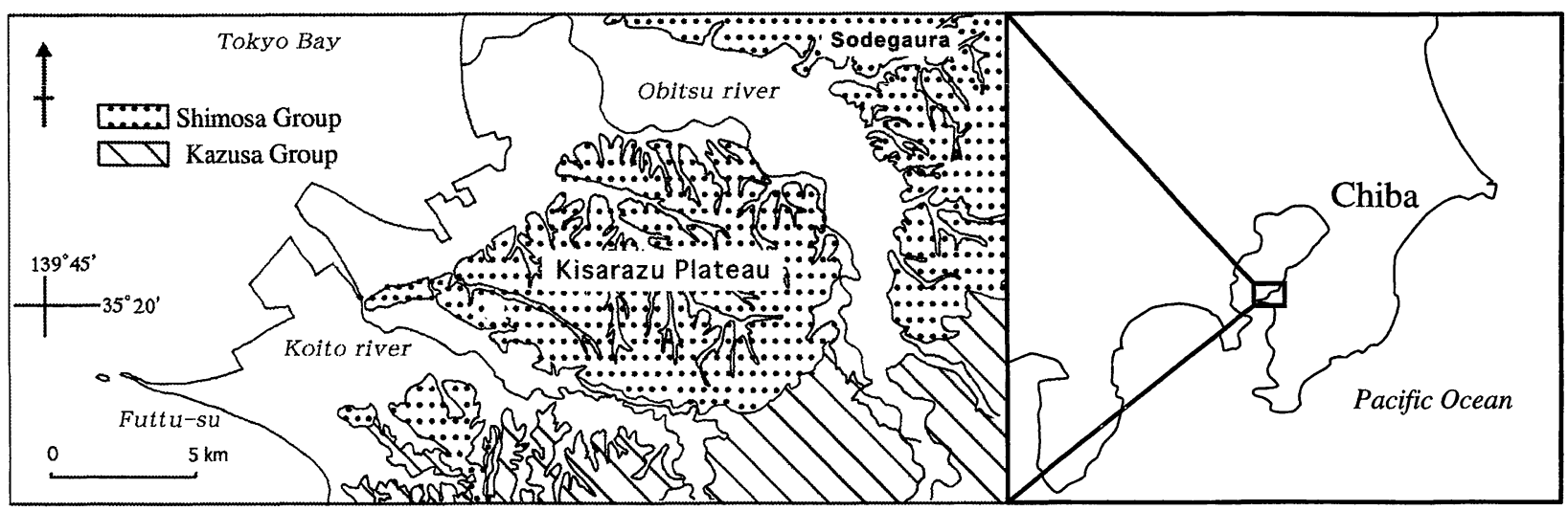

b

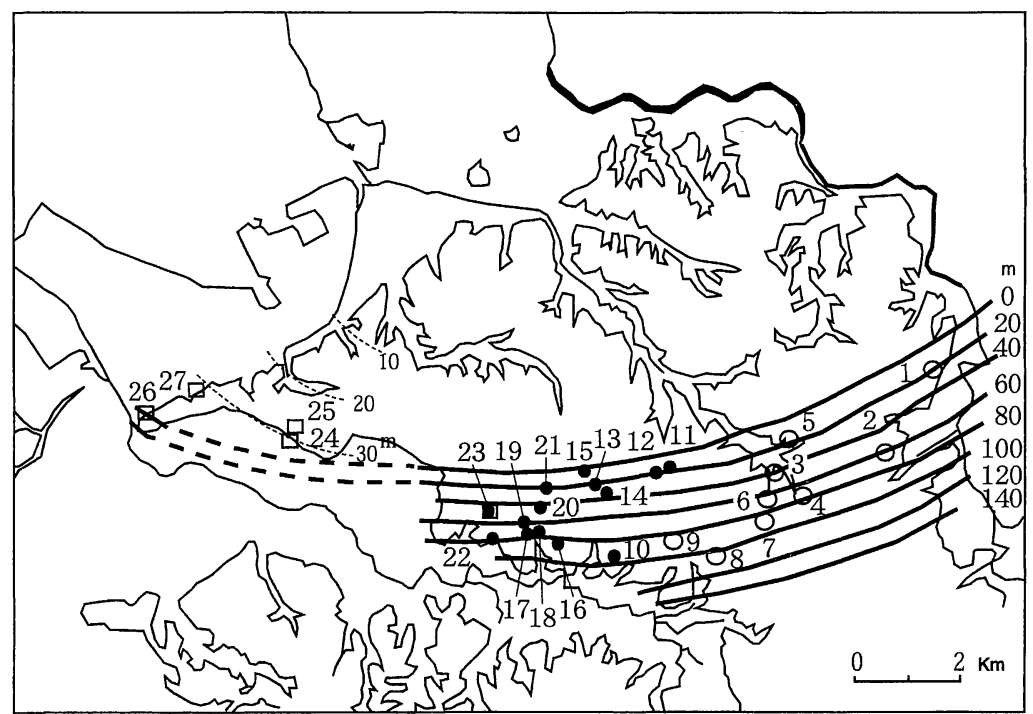

Fig. 1 a. Location and geologic map of the Kisarazu Plateau, Chiba Prefecture,central Japan.

b. Location of observation sites on the base contour lines of the Yabu Formation. Thin dotted lines indicate the base contour lines of the Kamiizumi Formation. Each symbol shows the facies of observation sites $(\bigcirc$; sands, $\bigcirc$; alternation of sands and muds, $\square$; sand- dominated alternation).

テフラを用いて薮層の分布を明確にし，その堆積相 解析から堆積システムを検討した。 その結果, 薮層 の基底面の形状之堆積相分布から古東京湾の湾口付 近に発達する砂嘴一内湾システムが復元された。 ま た, 堆積システムの变遷から薮層のシークェンス層 序を考察した。薮層は, 1 回の水河性海水準变動に 対応して形成され，砂嘴の発達は海水準上昇期に生 じ，また，高海水準期から海水準降下期には湾の埋 積がおこっていることが明らかになった。

\section{調 査 地 域}

木更津台地は下総台地の南部に位置し, 小櫃川と 小糸川低地に挟まれる地域である（Fig. 1)。台地の
標高は約 $20 \mathrm{~m} \sim 160 \mathrm{~m}$ で，台地面は約 $1^{\circ}$ で北北西 に傾いている，下総層群の全層準が分布する，当地 域の層序については，いくつかの見解があり統一さ れてはいなかったが (小島, 1966 ; 青木・馬場, 1971 ; Yajima, 1978 ; 杉原ほか, 1978)，模式地に分 布する指標テフラの詳細な追跡がおこなわれた結果 （佐藤，1994；1997），その実態が明らかになってい る (佐藤，投稿中)，すなわち，薮層の指標テフラ $\mathrm{Yb} 0 ， 2 ， 3 ， 4$ と薮層上位の上泉層の $\mathrm{Km} 2$ が鍵層と なり，模式地との対比がおこなわれている，木更津 台地の薮層は台地の南部で東西に連続してみること ができるが (Fig. 1b，2）, 分布地域の東部には比較 的厚い砂層がみとめられ, 薮層の下部層準にみられ 


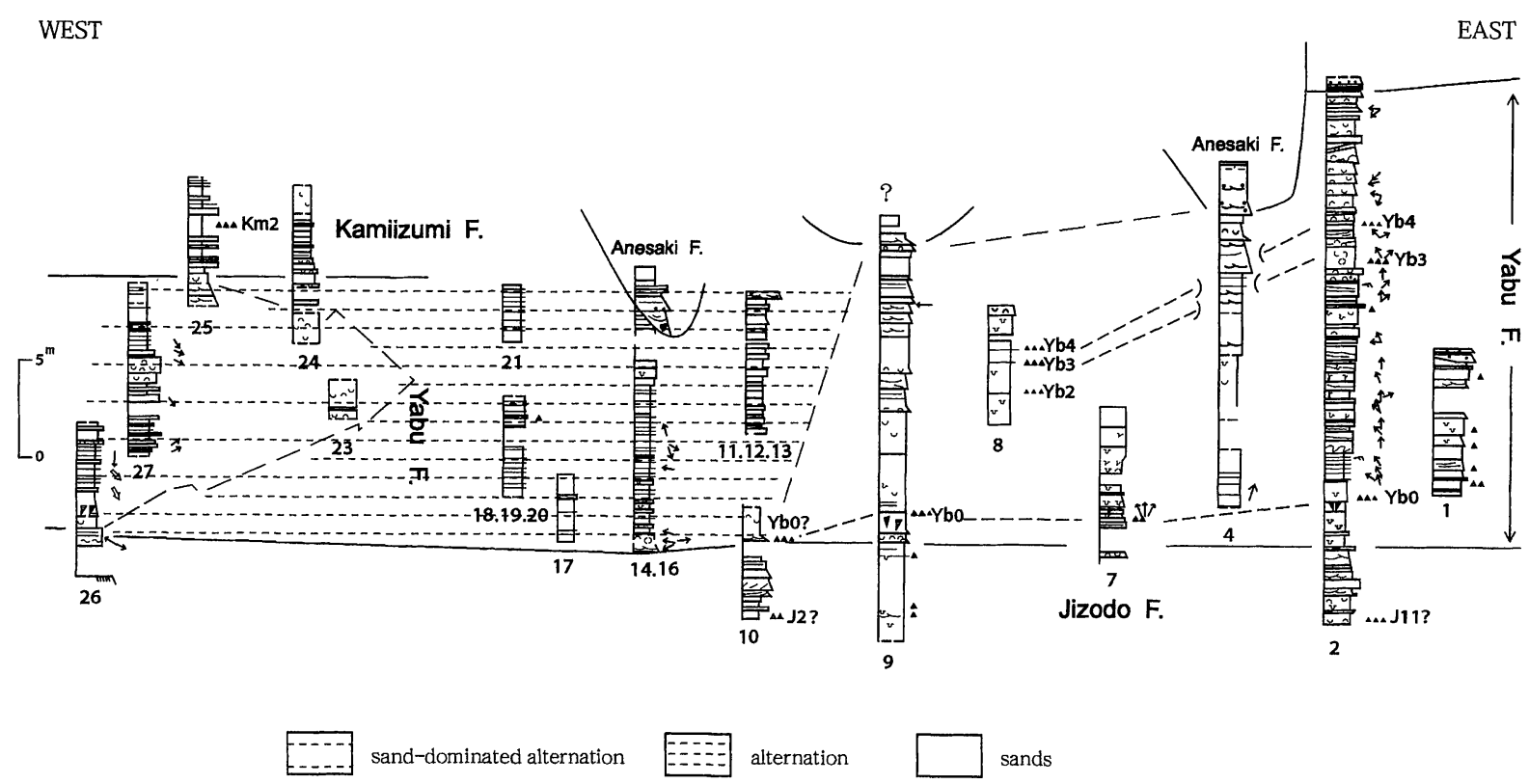

Fig. 2 East - west geologic cross-section along southern part of the the Kisarazu Plateau. Arrows show paleo-currents inferred from cross-beds. Bold arrows show paleo-currents inferred from foreset beds. The localities are shown in Fig. 1 b.

る $\mathrm{Yb} 0$ および中部の $\mathrm{Yb} 2 ， 3 ， 4$ が挟まれる. 中央 部には砂泥互層が発達し, Yb 0 と下位層準の地蔵 堂層の J 2 の可能性のあるテラフが認められる. 西 方にいくほど砂がちの砂泥互層となり，ここでは薮 層の指標テフラはみつかっていないが，上位に上泉 層の $\mathrm{Km} 2$ が認められる.

\section{堆積相と推定される堆積環境}

分布地域の東部の薮層は堆積相 I 〜 IVに分けられ る (Fig. 2 の Loc. 1 9, Fig. 3).

\section{堆積相 I}

基底は明瞭であり，砂質シルト層からなる。下部 は生物擾乱が激しく木片を含む.中部にカキ (Crassostrea gigas) が多産し礁をなす。上部は砂層 を頻繁に挟む. 厚さ約 $7 \mathrm{~m}$.

<堆積環境 $>$ Crassostrea 属は内湾汽水域の砂泥底 に密集して生息し，干潟に礁をつくって㧍り（鎮西， 1982)，沖積層では溺れ谷の湾奥や河口にみられる 干潟群集の主構成種となっている(松島, 1984).し たがって，このようなカキ礁は潮間帯の存在を示 し, 堆積相 I は内湾泥質干潟の堆積物と考えられ る.

\section{堆積相 II}

下位の堆積相とは漸移的である。北ないしは北東 に傾く大規模なフォーセット層理（フォーセット高 約 $15 \mathrm{~m}$ ) が認められる (Fig. $4 \mathrm{a}$ ). フォーセット層 理は細粒〜中粒砂とシルト〜極細粒砂の互層からな る。フォーセット層理の傾きは上方でやや急になり 細粒〜中粒砂層の厚さが増し, コンケイブ型を示 す. 細粒〜中粒砂層中には, 内部構造として平行層 理, 平板型斜交層理 (Fig. $4 \mathrm{~b}$ ), やや浅いトラフ型 斜交層理などがみられ，上部にしばしばリップル葉 理が認められる。コンボリュート構造が層理の下部 によく認められる。この層理の古流向はばらつきが みられるが北西向きまたは北向きが得られ，北西向 きが優勢である。また，リップル葉理の古流向は北 西向きまたは南西向きの 2 方向認められる，砂層中 にはマガキ，バカガイ (Mactra chinensis) などが 散在する. シルト〜極細粒砂層は薄い泥層としばし ば互層しリップル葉理が認められる。薄い泥層は マッドドレイプスをなす場合あある。泥層中には植 物片がしばしば含まれる。厚さ約 $20 \mathrm{~m}$.

<堆積環境>堆積相 II には, 下位の堆積相からの再 堆積と考えられるマガキや植物片を含み, また，潮 下帯から水深 $10 \mathrm{~m}$ 程度に生息するバカガイがみら れることから，比較的浅い環境が示唆される．また， 


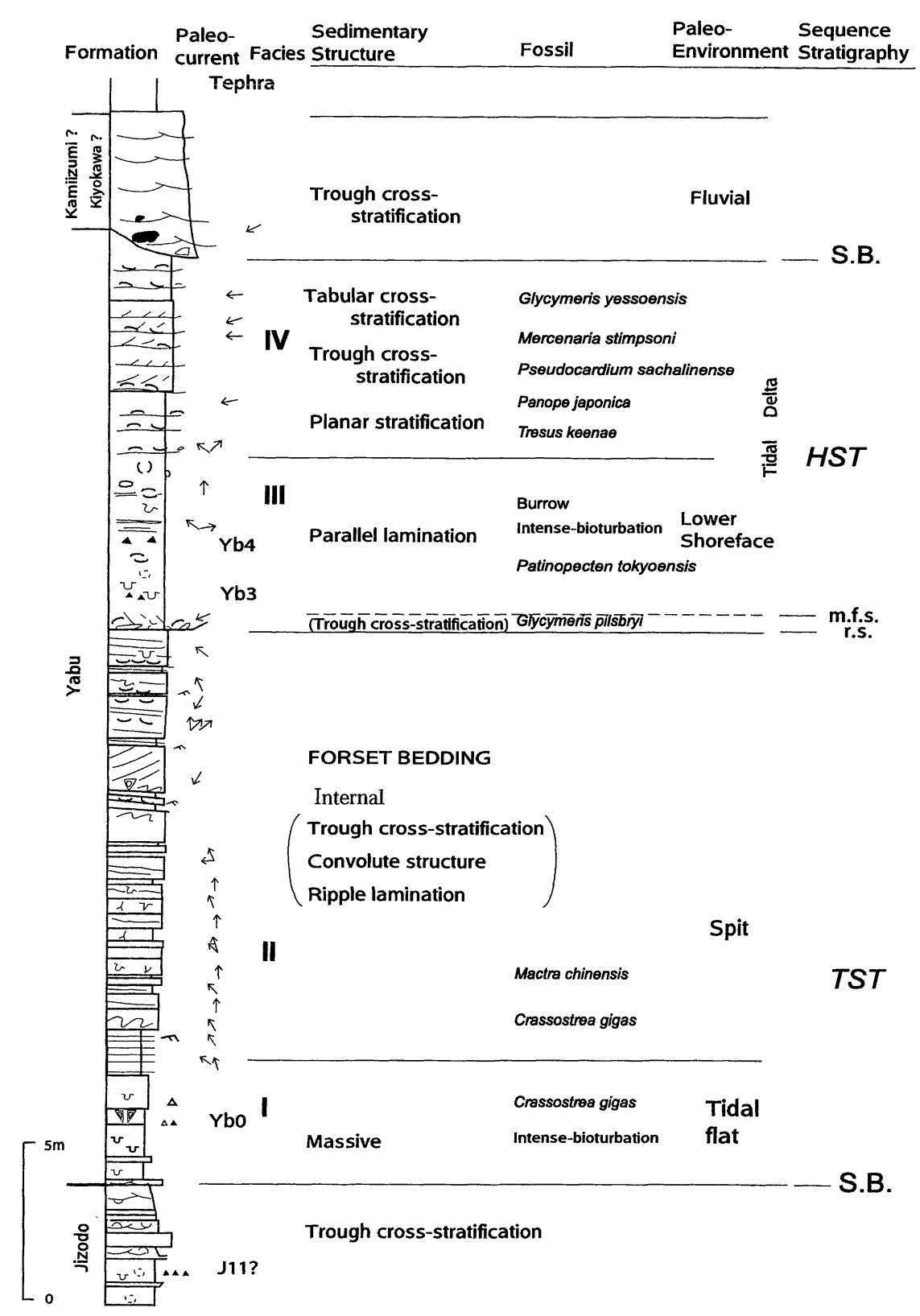

Fig. 3 Generalized facies succession of the eastern part (S.B. ; sequence boundary, r.s. ; ravinement surface, m.f.s.; maximum flooding surface, HST; highstand systems tract, TST; transgressive systems tract). Symbols used in the columnar section are defined in Fig. 5.

大規模なフォーセット層理は三角州や砂嘴の内部構 造にしばしばみられる屯のである (Posma and Roep, 1985 ; 岡崎・増田, 1992 ; 下総台地研究グルー プ, 1999 ; 岡崎ほか, 2000 ; Hiroki and Masuda, 2000).ここでは, この堆積物の上位に河川堆積物が 認められないことから砂嘴の堆積物の可能性が考え られる。

\section{堆積相 III}

基底面は明瞭な侵食面を示し，露頭でみられる最 大侵食量は約 $4 \mathrm{~m}$ である. 侵食面上には, 硬質頁岩 や固結した泥岩や砂岩磁（最大長径約 $20 \mathrm{~cm}$ ）がみ られ, 多種の貝化石が離弁した殼を入れ子にした状 態で密集する．固結した泥岩や砂岩礫にはしばしば 穿孔貝による孔がみられる。まれにこれらがトラフ 

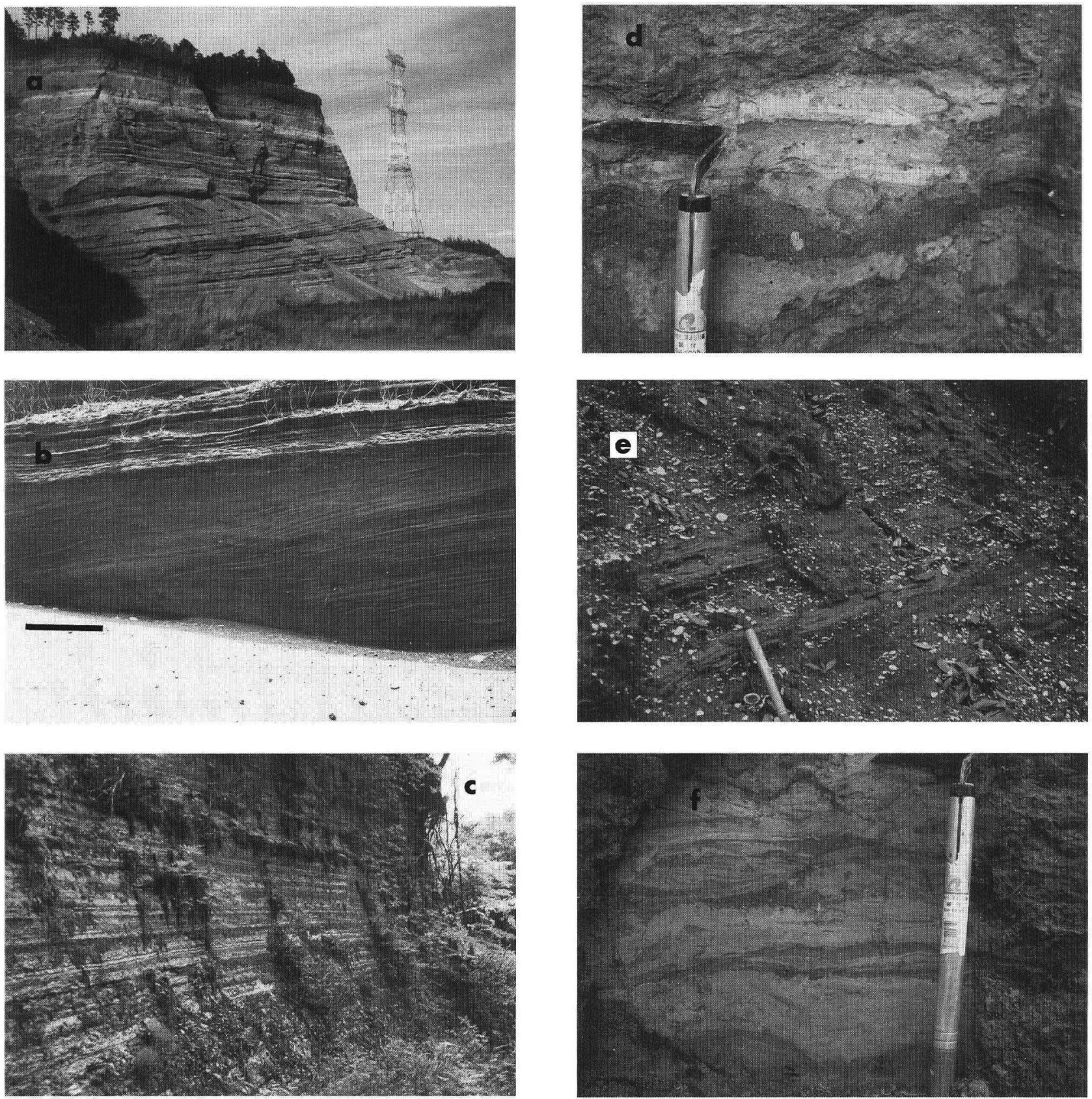

Fig. 4 a. Facies unit II (the lower part of the photograph) is characterized by large forset bedding. Facies unit III (the upper part of the photograph) overlies the ravinement surface. The height of the outcrop is about $60 \mathrm{~m}$ (Loc. 2).

b. Internal structures of the facies unit II (Loc. 2). Tabular cross stratification, ripple lamination at the top of the strata and convolute bedding at the bottom of the strata are observed.

c. Alternation of sands and muds of facies unit VII in the central part of the investigation area. The height of the outcrop is about $10 \mathrm{~m}$ (Loc. 14).

d. Graded bedding and parallel lamination in sands of facies unit VII. Burrows disturb primary structures (Loc. 14). The trowel is $15 \mathrm{~cm}$ long.

e. Coarser and thicker sand layers of facies VIII including molluscan shell fragments are intercalated with muds layers (Loc. 27). The trowel is $30 \mathrm{~cm}$ long.

f. Ripple laminations of facies IX (Loc. 27). The trowel is $30 \mathrm{~cm}$ long. 
型斜交層理をなすところあある。この直上の層準で みられる化石群は，暖流系下部浅海帯に生息する二 枚貝のビロードタマキガイ (Glycymeris pilsbryi) を中心としている．さらにこの上位は塊状の細粒砂 からなり，管状の生痕化石が多く含まれる．合弁の トウキョウホタテガイ (Patinopecten tokyoensis) が多く産出し, 深潜没型二枚貝であるナミガイ (Panopea japonica) やミルクイ (Tresus keenae) が自生の産状でみられる。層厚約 1-4 m.

<堆積環境 $>$ 基底にみられる侵食面上には異地性の 礫や貝化石が密集するので, この侵食面は砂嘴の上 面に波浪や潮流によって形成されるラビンメント面 と考えられる。このラグ堆積物には堆積時にすでに 固結していたと考えられる泥岩や砂礫が認められ, 以前この近くに波食台が形成されていたことが推定 される。上位の細粒砂には自生的産状の貝化石や管 状の生痕化石が多くみられる，生息姿勢を保った自
生の産状の貝化石は海底下数 $10 \mathrm{~cm}$ に潜って棲む深 潜没者のみで，このことは，深潜没者が生息してい た深度までは侵食が及ばなかったことを示してい る。また，海底表面で自由生活をおくる二枚貝であ るトウキョウホタテガイが合弁で多く産出すること は, それらの貝類が死後急速に埋没したことを示す と考えられる。これらのことから，本相は波や流れ による侵食よりも, むしろ暴風時などに急速な堆積 物の供給を受ける環境で堆積したことが推定され， 下部外浜の堆積物と考えられる。

\section{堆積相 IV}

下位の堆積相とは漸移的である。細粒〜粗粒砂層 からなり上方に粗粒化する。平板型斜交層理やトラ フ型斜交層理が発達する. 寒流系上部浅海帯に生息 するエゾタマキガイ (Glycymeris yessoensis), ビ ノスガイ (Mercenaria stimpsoni), ウバガイ

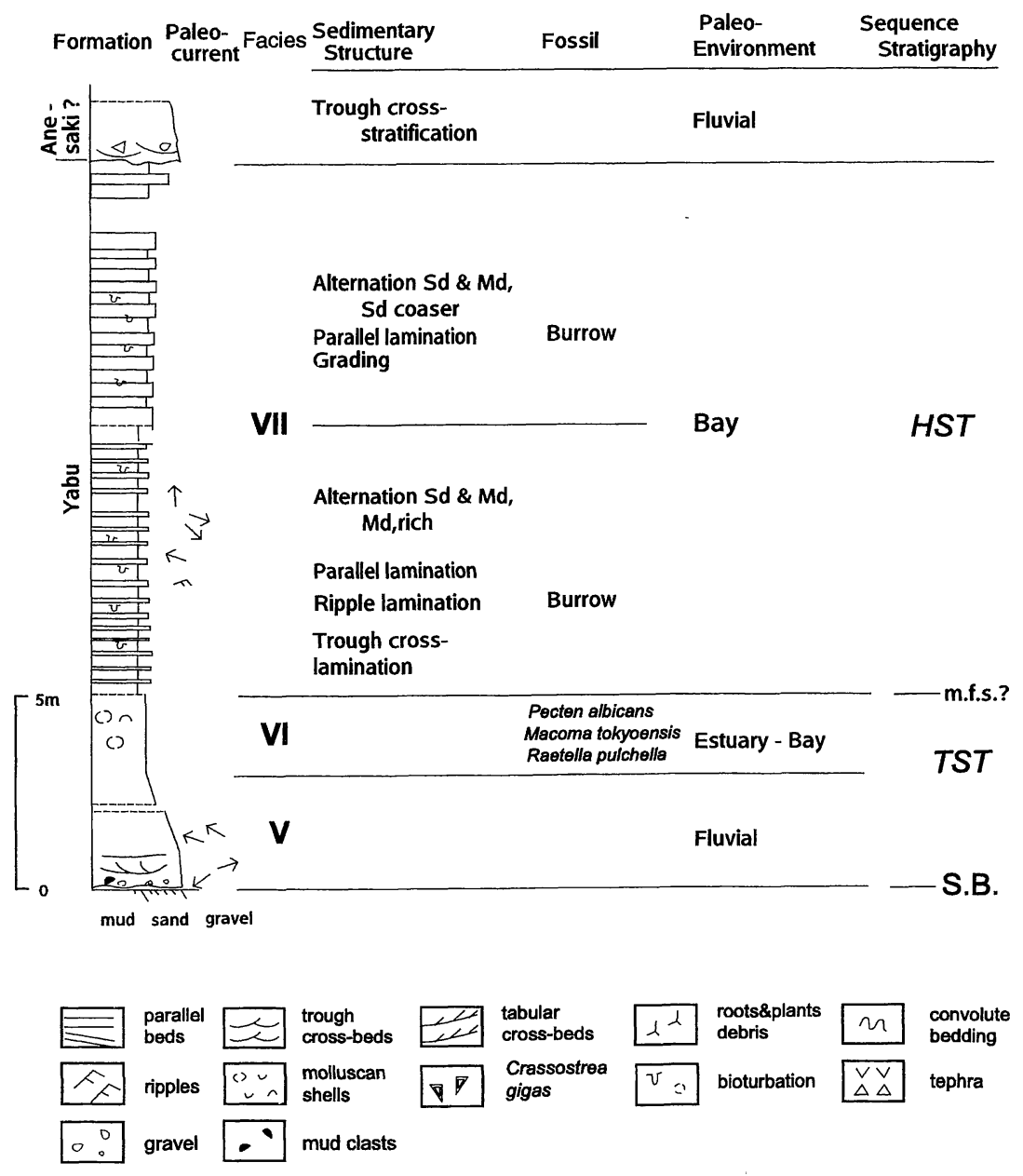

Fig. 5 Generalized facies succession of the central part. 
(Pseudocardium sachalinense) などを産する。斜 交層理から得られる古流向は，下部では 2 万向がみ られるが上部は西向きが卓越する。厚さ約 $7 \mathrm{~m}$ 以 上.

<堆積環境 $>$ 堆積相IV は上方に粗粒化し，平板型斜 交層理が発達し，古流向に 2 方向がみとめられるこ となどから潮汐三角州の可能性が考えられる（岡 崎・増田, 1992).

中央部にみられる薮層は堆積相 $\mathrm{V} \sim \mathrm{VII}$ に分けられ る. 特に堆積相VII連続的に広く分布する（Fig. 2 の Loc. 10〜20, Fig. 1 b, Fig. 5).

\section{堆積相 V}

基底にチャネル状侵食面が認められる。細礫を含 む細粒〜中粒砂からなる。下部には泥層の偽㗜が多 く含まれる.トラフ型斜交層理が発達し, 古流向は ほぼ西向きが優勢である.

<堆積環境 $>$ 堆積相 V はチャネル状の堆積様式を示 し，一方向の卓越した古流向を示すトラフ型斜交層 理がみられることから，河川堆積物と考えられる。

\section{堆積相 VI}

下位の堆積相之の関係は漸移である。青灰色の塊 状泥質砂層からなる。ゴイサギ（Macoma tokyoensis), チョノハナガイ (Raetella pulchella), イタヤ ガイ (Pecten albicans) などの二枚貝化石を含む. ゴイサギ，チヨノ八ナガイは合弁でみられ，とくに ゴイサギは生息姿勢を保っている，厚さは約 $1 \mathrm{~m}$ 以 上.

〈堆積環境＞堆積相VIに含まれるゴイサギ，チヨノ 八ナガイは原地性と考えられ，いずれも内湾潮下帯 〜 $100 \mathrm{~m}$ の砂泥〜泥底に生息する種であり，やや深 い内湾砂泥底であったと考えることが可能である。 このような層相と化石群集は沖積層の溺れ谷の埋積 物にも類似する（松島，1984）.

\section{堆積相 VII}

下位の堆積相とは漸移関係である。極細粒〜細粒 砂層（数～ $20 \mathrm{~cm}$ ） と泥層（数 $10 \mathrm{~cm}$ ）の互層から なる (Fig. 4c)。砂層中には平行葉理, トラフ型斜 交葉理が認められ，級化構造がみられる場合あある (Fig. 4d). Rosselia sp.などの生痕化石が多くみら れる。堆積相 VIIは下部と上部にわけることができ, 上部は下部より砂層, 泥層ともに粒径がやや粗くな
る. 厚さ約 $10 \mathrm{~m}$ 以上.

<堆積環境＞砂層の初生的堆積構造はしばしば牛痕 によって乱されているが，まれに級化構造や平行葉 理がみとめられる。このような砂層はストーム堆積 物が暴浪時の波浪作用限界水深より深い泥底に乱泥 流的な様式で堆積したものと考えられる（Walker, 1984). また, この砂泥互層は下位の内湾泥層と漸移 的であることから, 内湾の泥底の堆積物である可能 性がある。

台地の西部に認められる薮層は堆積相 VIII 〜 IX に分 けられるが，側方变化が激しい（Fig. 2 の Loc. 23〜 27, Fig. 6).

\section{堆積相VIII}

砂泥互層（それぞれ数 $\mathrm{cm} \sim 10 \mathrm{~cm}$ 程度）からな り，砂層中には八ンモック状斜交層理がみられる。 泥層には生痕化石が認められ上部にまれに植物片が 含まれる，挟まれる砂層で比較的厚い（約 $20 \mathrm{~cm}$ ) あのは, 細砂まじりの中粒〜粗粒砂層からなり，貝 化石片が多く含まれる (Fig. $4 \mathrm{e}$ ). 含まれる貝化石 はアサリ（Ruditapes philippinarum）を主体と し，ウバガイやエゾタマキガイを伴っている，この 含貝化石砂層は平行層理を示し，また，上部にいく ほど厚さが増して頻繁に挟まれるようになる，砂泥 互層全体はフォーセット状に東にゆるく傾いてい る。また, 平行層理などから得られる古流向もほぼ 南東〜北東方向を向く. 厚さ $12 \mathrm{~m}$ 以上.

<堆積環境 $>$ 砂層に含まれる貝化石の優占種である アサリは内湾潮間帯から水深 $10 \mathrm{~m}$ までの砂泥底に あぐってすむ種である. 現在, 調査地域南方に位置 する富津砂州の内湾側の細砂底にはアサリを主体と する内湾砂底群集が認められる(茅根, 1991)。これ らのことからこの砂泥互層も内湾の堆積物であるこ とが考えられる. 砂泥互層の砂層には八ンモック状 斜交層理がみられ, より厚い砂層には貝化石の破片 を多く含み平行層理などが認められることから，ス トーム時に内湾の泥底に運び込まれた堆積物之考え られる。また，この古流向はほぼ西から東のあのが 優勢であることから，ここより西方にアサリの生息 する干潟環境が存在したことが示唆される。 また， アサリと同時に含まれるウバガイやエゾタマキガイ などの寒流系上部浅海帯種からは, やや冷温で外洋 の影響が推定される(小島，1966)。したがって，こ れらの貝化石は，上記の干潟をのせる地形的高まり 


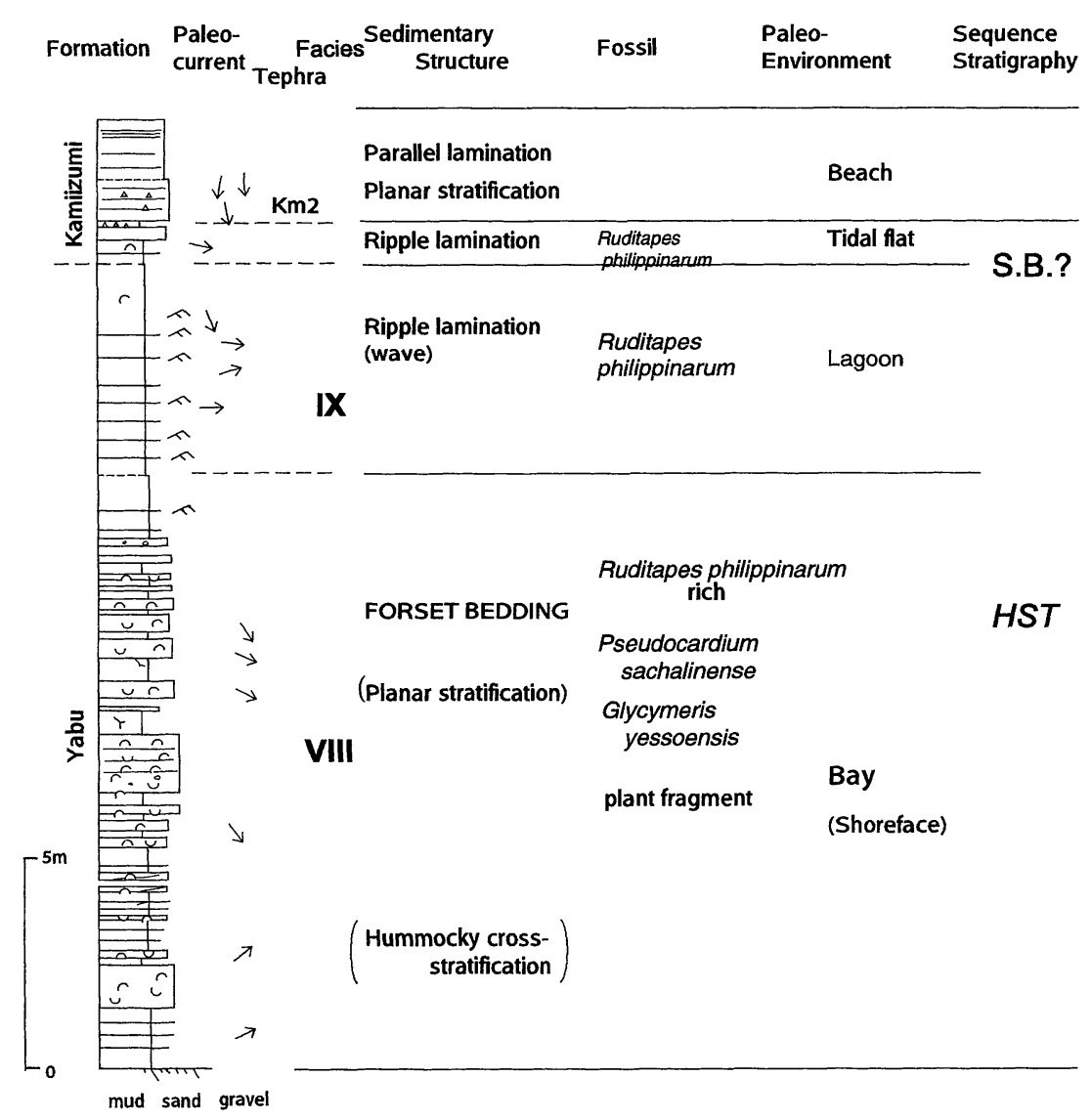

Fig. 6 Generalized facies succession of the western part. Symbols used in the columnar section are defined in Fig. 5.

のより西方の外洋環境の強い海域からその高まりを こえて流入した可能性も考えられる.

\section{堆積相 IX}

下位の堆積相から漸移するシルト〜細粒砂層と泥 層の互層からなる．砂層中にはウェーブリップル葉 理がしばしばみられる（Fig. $4 \mathrm{~d}$ ). 古流向は東向き である，泥層中には殼の溶けた貝化石（アサリ）が まれに含まれる。

<堆積環境>波の作用が定常的にみられること, 泥 層中に内湾環境を示すアサリが自生の状態で含まれ ることから静穏時の波浪水深以浅の小規模な閉塞 域，潟の堆積物であることが考えられる。

\section{砂嘴-内湾システム}

次にこれらの堆積相が形成する堆積システムにつ いて考察する.

\section{（1）基底面等高線図と古地形}

Fig. $1 \mathrm{~b}$ の実線は，木更津台地の薮層の基底面等 高線を示している（佐藤，投稿中）。基底面等高線 は，各露頭で挟在する指標テフラを用いて層準を認 定し，藪層の基底の標高を 2.5 万分の 1 または 1 万 分の 1 の地形図に基づいて求めたものである。この 基底面等高線図は 2 つのことを意味している．初生 的な堆積盆の形状とその後の構造運動による变位で ある．薮層の基底面等高線は木更津台地の南部で大 きく湾曲し，東部から中部で北西方向に西部で北よ りに傾いている，台地の西端では，薮層の基底のほ とんどが沖積面下になるため基底面等高線は書けな いが，薮層の層相分布や上位の上泉層の基底面等高 線からは北東傾斜が認められる（小島，1966； Yajima, 1978）（Fig. 2)。これらの傾斜角度は北西 方向には約 $3.0^{\circ}$, 北東方向に $0.5 \sim 1^{\circ}$ である.これら を堆積性の傾斜，例えばこの地域の現在の河川や海 浜勾配と比べてみると, 養老川や小櫃川で平均約 1 / 
250 (約 $0.2^{\circ}$ ）（鹿島，1982 より），小樻川干潟面では 約 $1 \sim 2 / 1000$ (約 $0.1^{\circ}$ 以下)（斎藤ほか, 1993 より） である。したがって，基底面等高線の傾斜はこれら より急で，特に北西傾斜の值は有意に大きい，房総 半島中北部では下総層群の北西方の傾動運動（鹿島 一房総隆起帯; 貝塚，1974）がよく知られており，調 查地域の北西方向の急傾斜はこの傾動運動の影響を 受けていると考えられる。，一方，西端での北東傾斜 は地蔵堂層から上泉層までみられるが，清川層以降 は認められず北西方向の一方的な傾斜のみになる (小島, 1966 ; Yajima, 1978 ; 佐藤, 投稿中). した がって，この湾曲構造は別の運動が影響している可 能性が，また，その運動は薮層の基底形状を規制し ていた可能性が考えられる．次に湾曲構造が薮層堆 積時から存在したとすると，この構造の各部で層相 が変化することが期待される，そこで，この地域の 層相分布をみてみる．基底面等高線の最大傾斜が北 西でややゆるやかなところには東部の厚い砂層 （Fig. 1bの○）が分布する．中央部の基底面等高線 が湾曲する湾央になるところには厚い砂泥互層 （○）が位置する，西端の砂がち砂泥互層（（）の分 布は基底面がゆるやかに北東傾斜になって变化する ところにあたる。このように基底面等高線の形状と ともに層相が変化し，この基底面等高線は堆積時の 古地形を反映していると考えられる，また，湾央部 とその西方に分布する砂泥互層は内湾の堆積物之考 えられ，したがって，この湾曲構造は古東京湾南縁 に枝湾が存在したこと指示している可能性が高い.

ちなみに，基底面等高線が一方向に傾き湾曲構造を 示さない清川層では，河川堆積物が全体に卓越する (佐藤，投稿中).

\section{（2）砂嘴-内湾システム}

各堆積相とこの小湾との関係をみてみる．堆積相 II の大規模フォーセット層理をむつ細粒砂層は前述 したように，その形態と上位に河川堆積物がみられ ないことなどから砂嘴堆積物の可能性が考えられ る.この砂層はちょうご小湾の東の湾口に位置し, また，フォーセット層理の傾きの方向は北西で，湾 口を塞ぐ方向にのびており，湾口の砂嘴堆積物と考 えられる (Fig. 7). 一方, 堆積相VIIIは湾の西翼に位 置し，その西方に地形的高まりが推定される．砂泥 互層のフォーセット状の東へのゆるい傾きや，東か らの古流向を示す比較的厚い砂層を挟むことは，こ こが内湾の西端で湾央に向かってゆるく傾く泥底斜
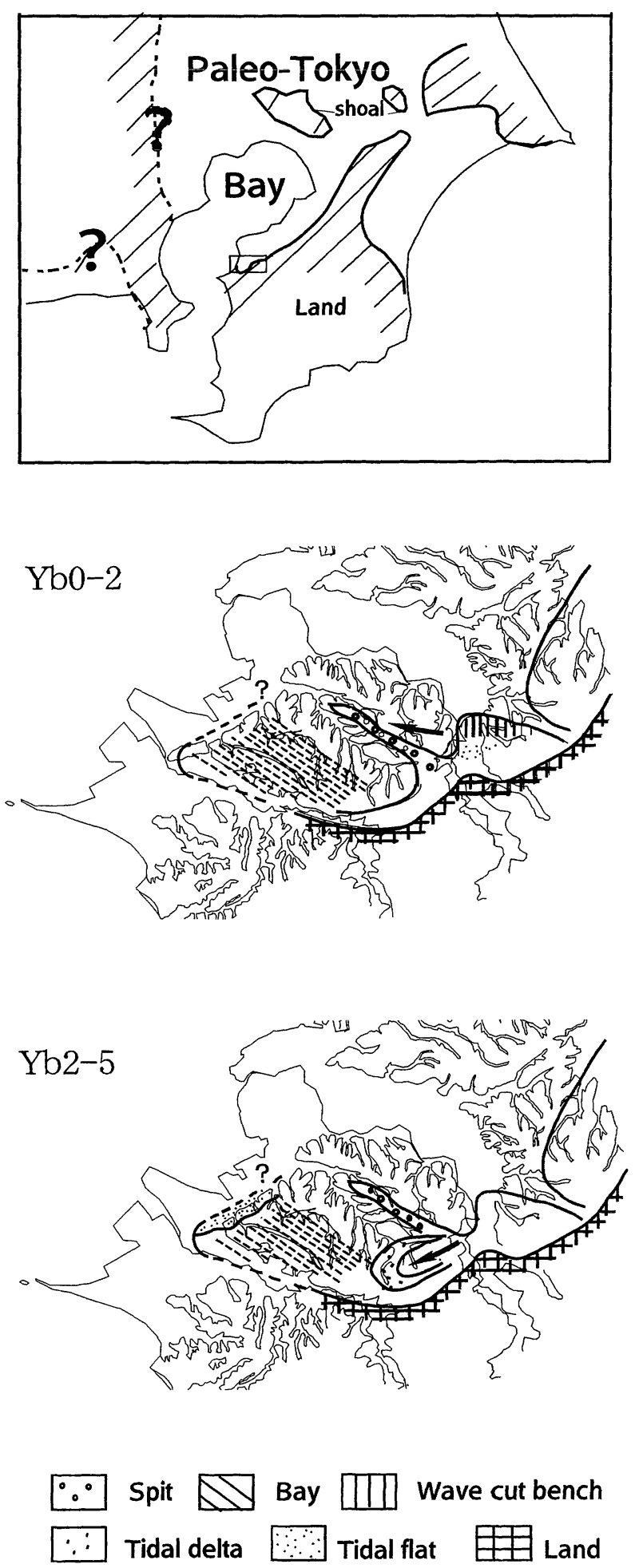

Fig. 7 Paleo- geographical figures of the Yabu Formation. $\mathrm{Yb} 0-2$ corresponds to the period of sea-level rising and $\mathrm{Yb} 2-5$ the period of sea-level falling. 
面であることを示していると考えられる。また， Yajima（1978）はここに含まれる介形虫化石につい て, 内湾砂底群集に岩礁地の潮間帯, アマモ場, 内 湾泥底に生息する種が混合していることを報告して いる．このことも上記のような環境を支持している と考えられる. 中央部の砂泥互層 (堆積相VII) はこ のような砂体に囲まれて堆積している内湾泥底の堆 積物であると考えられる。したがって，堆積相と古 流向からは砂嘴とその背後の閉塞された湾が考えら れ，基底面等高線図の湾曲構造と整合する．砂嘴堆 積物の上位および側方には, 砂嘴堆積物と斜交し て, 南西に前進する上げ潮潮汐三角州がみられる. 砂嘴の上位に海浜堆積物が認められないのは，この 潮汐三角州の下位のラビンメント面によって削剝さ れたためと考えられる。（内湾側は一般に海浜堆積 物の発達はよくない）また，一般に砂嘴の発達する 近傍にはその砂の供給源である波食台がみられる が，この地域では $\mathrm{Yb} 0$ をのせる波食台が東方に存 在する（岡崎ほか，投稿中）ことから，この付近が 相対的に高く砂の供給源になっていた可能性が考え られる。

この地域に砂嘴堆積物が発達したのは, 海岸線の 方向に变曲点が存在したこと, 下位に干潟堆積物が みられるように浅瀬が存在したこと，また，古東京 湾の湾口部に近く沿岸での流れが速かったことなど によると考えられる。このことは，この付近に完新 世の富津砂州が発達することからも推定される，潮 汐三角州が形成されたのは，比較的速い潮流によっ て砂が流入するものの，比較的大きく深い湾がなか なか埋積されなれなかったためと考えられる.

ここでみられる砂嘴堆積物とその背後の内湾堆積 物, それと漸移して側方拉よび上方にみられる潮汐 三角州や潟堆積物, また，下位の干潟堆積物は，一 連の関連する堆積相群として捉えられることができ る。これらをまとめて砂嘴一内湾システムと呼ぶこ ととする.

\section{（3） シークェンス層序と海水準変動}

堆積相システムの変遷を指標テフラに基づいてみ ていくと次のようである.

$\mathrm{Yb} 0$ 堆積以前に, 湾の東部では泥質干潟上に力 キ礁が発達する。 Yb0 から Yb 2 堆積時には, 東部 は浅瀬になり，沿岸流や潮流により北西方向に砂嘴 の急速な発達がおこったことが推定される（Fig. 7).これらは海進期の堆積物であることが示唆され
る. 砂嘴のフォーセット層理は流速の比較的速い場 合に形成されるコンケイブ型を示し, 下位の堆積相 からの再堆積と考えられるマガキや植物片を多く含 むことから，干潟が沈水した浅瀬上に急速に砂嘴が 前進したことが推定される. 湾中央部では東部の湾 口で砂がトラップされるために泥底が広がる，西部 地域には薮層のテフラが含まれないので堆積時期が 明確ではないが，湾の南西方にも干潟が広がりカキ 礁が発達する（Fig. 2 の Loc. 26）。砂嘴の上位には ラビンメント面がみられ, その直上にこの層準で最 屯深い貝化石が産出することから, 海進期のラビン メント面であることがわかる. Yb 4 堆積後は, 東部 では湾奥方向に上げ潮潮汐三角州が前進する。 それ によって湾奥もやや砂質になる．西部は上方に向 かって内湾から潟堆積物に急速に浅海化することか ら，周辺の地形的高まりから埋積がおこり，内湾の 西部を塞いだ可能性がある。したがってこれらは海 退期の堆積物と考えられる。このような堆積システ ムの变遷からこれらは 1 つの堆積シークェンスを形 成していたと考えられる。薮層のテフラのフィッ ショントラック年代からは, 藪層の堆積時期は酸素 同位体比ステージ 10〜8 の堆積物と考えられる（杉 原ほか，1978；増田，1988）。したがって，木更津台 地の薮層の堆積システムの発達は, 水河性海水準変 動が大きく影響したと考えられる。また，鎌滝 （1999）は木更津台地の北東方の薮層においてシー クェンス層序を検討し, その貝化石群集の組成变化 からほぼ Yb 2 の直下層準が最大海氾濫面としてい るが，本調査地域の結果もこれと矛盾しない。調査 地域の東部地域においては薮層基底のシークェンス 境界からラビンメント面直上の最大海氾濫面までが 海進期堆積体（TST）と考えられ，これは泥質干潟 堆積物（堆積相 I ）とその上位の砂嘴堆積物（堆積 相 II）からなる，海水準上昇の停滞期に急速に砂嘴 が発達したと考えられる。 また，高海水準期に潮汐 三角州が前進し, 高海面期堆積体 (HST) を形成す る. 中央部の湾央では, 堆積物の供給が最も少ない ことから最大海氾濫面の認定は難しいが, 内湾堆積 物（堆積相VII）の下位の溺れ谷堆積物（堆積相VI） に産出する貝化石汃らは前述の最大海氾濫面と同程 度むしくはやや浅い深度が推定される。 また，上部 では挟まれる砂層の粒径がやや粗くなることから， 最大海氾濫面は内湾堆積物の基底もしくは中部に求 められる可能性がある. 西部は, 薮層の指標テフラ がみつからないことから, どの時期の堆積物である 
かは特定されないが，内湾堆積物（堆積相VIII）の貝 化石には，冷温種がまじり，また，上位の堆積相が 潟堆積物へと漸移することから，全体として高海面 期から海水準下降期の堆積物と考えられ，これらは HST を構成する.

\section{謝辞}

本研究をすすめるにあたり京都大学理学部増田富 士雄教授，地質調查所海洋地質部の斎藤文紀博士に は有益なご助言をいただいた。図の作成について寒 河江美里さんのご協力を得た．以上の方々に感謝の 意を表します。本研究は，文部省科学研究費補助金 （課題番号 10640445）の援助を受けて実施した.

\section{文献}

青木直昭・馬場勝良， 1971 : 木更津一市原地域の瀬又，上泉およ び成田層の貝化石群とその産出層準，地質雑，77，137-151. 鎮西清高, 1982 : 力キの古生態学. 化石, 31, 27-34.

Hiroki, Y. and Masuda, F., 2000 : Gravelly spit deposits in a transgressive systems tract : the Pleistocene Higashikanbe Gravel, central Japan. Sediment, 47, 135149.

貝塚爽平，1974：関東地方の島孤における位置と第四紀地殼変 動. 垣見俊弘・鈴木尉元編「関東地方の地震と地款变動」, ラ ティス，東京，99-118.

鎌滝孝信, 1999 : 堆積速度に影響された貝化石群 : 中部更新統下 総層群薮層の例，地質学論集，第 54 号，175-183.

鹿島 薰, 1982 : 小櫃川流域と養老川流域の更新世末期以降の地 形発達史. 地理評, 55 (2), 113-128.

茅根 創, 1991 : 房総半島富津砂州の形成に伴う完新世の貝類群 集の変遷，第四紀研究，30，265-280.

小島伸夫, 1966 : 東京湾の南東沿岸地域の成田層群に含まれる貝 化石群集について. 成田層群の研究 第 7 報, 地質雑, 72 , 573-583.

増田富士雄, 1988 : ダイナミック地層学一古東京湾の堆積相解析 から一，その 1 基礎編). 応用地質，29，312-321.

松島義章, 1984 : 日本列島における後水期の浅海性貝類群集一特
に環境变遷に伴うその時間・空間的变遷一. Bull. Kanagawa Pref. Mus. no. 15, 37-109.

岡崎浩子 ・増田富士雄, 1992 : 古東京湾地域の堆積システム. 地 質雑, 98, 235-258.

岡崎浩子 - 伊左治鉏司 - 中里裕臣, 2000 : 更新統下総層群上泉層 にみられるギルバート型粗粒三角州. 地質雑, 106, 461-471.

岡崎浩子 - 中里裕臣・佐藤弘幸（投稿中）: “古東京湾” の成立之 堆積環境の変遷. 中博自報特別号 4 「房総半島の堆積相, 古 生物相变遷」

Postma, G. and Roep, T.B., 1985 : Resedimented conglomerates in the bottomsets of Gilbert-type gravel deltas. Jour. Sediment. Petrol., 55, 874-885.

斎藤文紀・茅根 創, 1989 : 富津砂州周辺海域の地形・堆積物と その変化について．第 15 回産業公害研究総合推進会議総会 研究発表資料, 128-129.

斎藤文紀・横田節哉・池田国昭・大島和雄, 1993 : 浅海環境の長 期的変遷過程の解明による最適立地の予測技術に関する研 究. 平成 4 年度公害特別研究報告集, 工業技術院，43- II-1 43- II - 22 .

斎藤文紀, 2000 : 房総半島東京湾側の沖積層と海水準变動. 日本 第四紀学会講演要旨, 166-167.

佐藤弘幸, 1994 : 木更津・君津周辺の下総層群の層序と構造. 日 本地質学会第 101 年学術大会演旨, 50 .

佐藤弘幸, 1997 : 下総層群薮層のシーケンス. 堆積学研究会 1997 年秋季研究集会プログラム講演要旨, 55-57.

佐藤弘幸（投稿中）: テフラからみた木更津台地の層序と構造. 中博自報特別号 4 「房総半島の堆積相, 古生物相変遷」

下総台地研究グループ，1999: 完新世後期海面変動と湾口砂嘴・ 波食棚・古環境亡の関係一千葉県坂川低地の例一. 地球科 学, 53, 359-373.

杉原重夫 · 新井房夫 - 町田 洋, 1978 : 房総半島北部の中・上部 更新統のテフロクロノロジー. 地質雑, 84, 583-600.

Yajima, M., 1978 : Quaternary ostracoda from Kisarazu near Tokyo. Trans. Proc. Palaeont. Soc. Japan, N. S., 112, 371409.

Walker, R.G., 1984 : Shelf and shallow marine sands. In : Facies Models, 2nd edn (Ed. R. G. Walker), Geosci. Can. Repr. Ser., 1, 141-170. 


\title{
中部更新統下総層群薮層から復元された砂嘴一内湾システム
}

\author{
岡崎 浩子・佐藤 弘幸・中里 裕臣・鎌滝 孝信,
}

2000, 堆積学研究, No. 52, 63-74

Okazaki, H., Sato, H., Nakazato, H. and Kamataki, T., 2000 : Spit-bay depositional system recognized in the Yabu Formation, Shimosa Group in the

Kisarazu Plateau, Chiba Prefecture, Japan.

Jour. Sed. Soc. Japan, No. 52, 63-74

調查地域である千葉県の木更津台地は, 中・上部下総層群の分布地域の南限すなわち古東京 湾の南縁にあたる。下総層群の下部層である薮層は下総台地に広く分布し, 酸素同位体比ス テージ 10〜8 の堆積物である. 本論文では, 調查地域で新たに報告された指標テフラを用いて 薮層の分布を明確にし, その堆積相解析から堆積システムを検討した。 その結果, 薮層の基底 面の形状と堆積相分布から, 古東京湾の枝湾に発達する砂嘴一内湾システムが復元された。 ま た, 薮層は, 1 回の水河性海水準変動に対応して形成され, 砂嘴の発達は海水準上昇期にま た，湾の埋積が高海水準期から海水準降下期におこっていることが明らかになった. 